\title{
To List or Not To List: Expectations versus Reality for Greek Shipping IPOs
}

Panos Mourdoukoutas, Abraham Stefanidis *

\section{Abstract:}

Sharing ownership with outside investors through an IPO has advantages and disadvantages that create dilemmas for company founders. It can further be a source of disappointment when expectations fall short of reality. That's not the case for the Greek ship owners who floated the shares of their companies to major US Exchanges in the early 2000s, however. The listing has met and even exceeded their expectations: Broadened their capital structure, improved image and prestige, strengthened bargaining power with creditors, and enhanced entrepreneurial opportunities

DOI: $10.2478 / \mathrm{v} 10033-009-0009-0$

\section{Introduction}

Equity financing through a private placement or an IPO has become a popular source of financing in recent years. In the 1990's, this trend was confined mostly to high-technology companies reaching for both the funds and the visibility associated with a successful IPO in a major Exchange, especially the American Stock Exchange (AMEX), the New York Stock Exchange (NYSE), and the National Association of Securities Dealers Automated Quotations (NASDAQ). In 1999 alone, 544 companies completed successfully an IPO in one of these exchanges raising $\$ 87.2$ million on average and $\$ 23.6$ billion in total (NYSE, 2001). In early 2000s, this trend was extended to traditional sectors, such as shipping. In 2005 alone, seven Greek shipping companies floated their shares in US Stock Exchanges, bringing the total number of listed Greek companies to 13.

Sharing ownership with outside investors through an IPO has advantages and disadvantages that create dilemmas for company founders. Taking a company public provides access to present and future equity financing, augments credibility, improves bargaining power with creditors, enhances corporate prestige, and fosters employee motivation. At the same time, public listing incurs direct and indirect costs, such as underwriting and registration fees, disclosure requirements, and exposes companies to unfriendly or hostile takeovers.

The advantages and disadvantages of an IPO may not be well known in advance, however. This is especially the case for indirect benefits, such as the improvement of corporate image and prestige and the extension of business relations that enhance the entrepreneurial function of the company that take time to materialize. This means that a post-IPO world may not be as rosy and cozy as anticipated when the IPO decision was made. So, to list or not to list?

\section{*Panos Mourdoukoutas}

Long Island University and Athens University

New York, United States of America

e-mail: panos.mourdoukoutas@liu.edu

\section{Abraham Stefanidis}

Long Island University and Athens University New York, United States of America

e-mail: avraam.stefanidis@liu.edu 
The answer to this question depends upon a number of additional factors that eventually tip the balance between benefits and costs, such as the state of the equity markets and each particular industry, and the company size -to mention but a few. Equity financing, for instance, is much easier in "bull" rather than in "bear" markets. Equity financing is also easier in industries on a cyclical upturn rather than downturn, especially for larger companies with solid financials, as has been the case with the Greek shipping industry in the early 2000s, the subject of this paper.

At that time, Greek ship owners had it all: A resurgence in global equity markets led by robust commodity prices, a cyclical upturn in both cargo volumes and rates, and a reputation as the world's most astound shipping tycoons that tipped the balance between listing benefits and costs in favor of the former. As our survey of 10 out of 13 Greek listed companies indicates, a listing in major US Exchanges, allowed them to augment and diversify their sources of financing, improve their image and prestige, strengthen bargaining power with creditors, and enhance their entrepreneurial opportunities -meeting and even exceeding their expectations.

Arguing this contention in more detail, the remaining of the paper is in two sections. The first section discusses some theoretical insights on the costs and benefits of going public, while the second section discusses the results of our survey.

\section{To List Or Not To List: Some Theoretical} Insights

As is the case with every business decision, the decision to go public through an IPO involves a number of direct and indirect costs and benefits that must be carefully addressed and evaluated.

One benefit of going public is the immediate (primary offering) and future (secondary offering) access to equity capital that can be used as an efficient exit mechanism for company owners and venture capitalists, debt retirement, capital expansion, and for "account rebalancing" (Black and Gilson, 1998; Pagano, Panetta \& Zingales, 1998; Brennan and Franks, 1997; Röell, 1996; Zingales, 1995).
Another benefit is improved liquidity and risk sharing. Listed shares are far more liquid than non-listed shares, which make them more appealing to investors, especially to those who take an opportunistic approach to investing (Ritter and Welch, 2002, Pagano, 1993, Amihud and Mendelson, 1988). Listed shares can be further part of a diverse portfolio, which appeals to conservative investors who prefer a diverse over a nondiverse portfolio of equities.

A third benefit is the enhanced visibility and corporate image that comes with increased publicity. Regulatory agencies and Exchanges require listed companies to release certain information to the public, and therefore are much more likely to receive the attention of mass-media than private enterprises. Press releases, interviews, news stories, analyst reports and daily stock market tables comprise a free and flexible communication mechanism that improves recognition among the company's current and future stakeholders (Pollock and Gulati, 2007, Cook et al., 2006; Frieder and Subrahmanyam, 2005).

A fourth benefit of going public is the signals it conveys to potential creditors about the financial health of the corporation (Deeds et al., 1997; Leland and Pyle, 1977). To qualify for an IPO, companies must comply with Exchange and government agency requirements that convey a positive signal to creditors about the financial health of the company. Therefore, IPO enhances financial transparency and improves bargaining power with banks and other financial institutions (Fombrun and Van Riel, 1998). Bankers, for instance, feel more comfortable lending funds to known companies that have already passed the screening test of a reputable institution, rather than to unknown companies that never took or failed such test. This implies that listed companies have a greater bargaining power when it comes to funding negotiations (Rajan, 1992). This is especially the case for companies in capital intensive industries, such as companies in the shipping.

A fifth benefit is the fostering of new business opportunities brought about by the enhanced credibility and corporate profile that attracts the attention of potential inter-organizational partners or alliance candidates, and new customers. Lenders, 
partners, and suppliers perceive listed companies as more reliable partners (low risk) than non-listed companies, strengthening existing business relationships and encouraging vertical and horizontal entrepreneurial networking (Ravasi and Marchisio, 2003; Barry et al., 1990).

A sixth benefit of going public is the introduction and implementation of equity- based compensation packages that improve the recruitment and retention of qualified managers and employees, aligning their interests with those of the corporation (Bolton \& von Thadden, 1998; Holmstrom \& Tirole, 1993).

In short, corporations that consider a public offering expect a number of benefits that range from broadening their capital structure and improved liquidity to the lowering of cost of capital and the expansion of business opportunities. These benefits must be compared and contrasted with a number of expected costs.

One cost of going public is investment banking fees, which account to around $7 \%$ of the issue value in the US and 6\% in Japan (Hansen, 2001; Chen \& Ritter, 2000).

Another cost is Exchange registration fees, due diligence and Stock Exchange listing fees, and auditing, certification and dissemination expenses (Barry et al., 1991). These expenses are rather fixed, in the range of $\$ 250,000-300,000$, and therefore they burden disproportionably smaller companies rather than larger companies (Ritter, 1987).

A third cost is underpricing, due to the asymmetry of information between corporate insiders and outsiders. In general, individual and institutional investors aren't as informed as insiders about the real value of the issuing firm, which affects negatively the average quality of the issuing firm and leads to underpricing of the shares issued to the public (Derrien and Kecskés, 2007, Ritter, 2003; Booth and Chua, 1996; Rock, 1986). Adverse selection cost is larger for younger and relatively young firms with a short track record and little visibility (Chemmanur and Fulgieri, 1999).

A fourth cost of going and remaining public is compliance with strict and explicit disclosure requirements that often makes an IPO much more costly than alternative sources of financing (Campbell,
1979). In the US, for instance, securities market regulations, such as the caveat emptor (buyer beware) require the disclosure of information that inevitably becomes available to third parties, including current and potential competitors (Yosha, 1995).

A fifth cost of going public is associated with decrease or loss of corporate control and vulnerability to the threat of unfriendly or hostile takeovers (Pagano and Röell, 1998).

In short, an IPO has a number of direct and indirect benefits that range from access to present and future equity financing, to enhancement of corporate prestige and employee motivation (see Table I). At the same time, an IPO has direct and indirect costs, such as underwriting and registration fees, disclosure requirements, and exposes companies to unfriendly or hostile takeovers.

Some IPO costs and benefits may not be fully known in advance, however. This is especially the case for indirect benefits, such as the enhancement of corporate image and prestige and the extension of business relations that upgrade the entrepreneurial function of the company that take time to materialize. This means that anticipated IPO benefits may fall short of actual IPO benefits, and in some cases, the gap between expectations and reality may be sufficient enough to tip the balance towards the costs.

In addition, IPO benefits and costs depend on macroeconomic and microeconomic conditions, such as the state of the equity markets or particular industries and the company size, that may broaden or narrow the gap between anticipated and actual IPO benefits (Pagano, Panetta \& Zingales, 1998; Röell, 1996). Equity financing, for instance, is more accessible in rising rather than in declining equity markets (Derrien and Kecskés, 2007). Equity financing is also easier in industries on a cyclical upturn rather than downturn, especially for larger companies with solid financials that lead their industry, as has been the case with the Greek shipping industry in the early 2000 s.

\section{Greek Shipping IPOs; Expectations versus Reality}

There have been the best and the worst times for the Greek shipping industry, which owns the world's 
second largest fleet in terms of tonnage, behind Japan (UNCTAD Secretariat, 2006). In the early 2000s, there was the best time. Greek ship owners had it all: First, a cyclical upturn in the shipping industry that created the need for additional capacity. Between 2002 and 2006, the Greek fleet has increased by about $7 \%$ annually, in terms of capacity, while in 2006 alone the Greek tonnage additions were 11 million deadweight tons (see Figure I). Second, a resurgence in global equity markets fueled by robust commodity prices, rising cargo volumes and rates (Grammenos and Marcoulis, 1996). Third a reputation as the world's most astounding shipping tycoons (Stefanidis et al., 2007).

These favorable conditions tipped the balance between listing benefits and costs for 13 companies that launched successful IPOs in US Exchanges (see Table II).

For years, Greek shipping companies have relied on plain or syndicated loans from Greek and Far East banks to finance and expand their operations, especially the upgrading and expansion of their fleet (Grammenos \& Choi, 1999). This finance structure is reflected in the high interest expense as a percent of EBIT. Even after going public, such an expense approaches or exceeds 50 percent of EBIT. Aries Maritime Transport's interest expense, for instance, accounts for close to 56 percent of EBIT; Quintana Maritime's percent is 49.24, and Omega Navigation's percent is 34.29. But which expected benefits tipped the decision of these companies to go public? Did expectations meet reality?

To address these questions, we formulated five propositions:

Proposition 1: Following an IPO, improved visibility of the shipping company increases its bargaining power with banks and other financial institutions.

Proposition 2: Following an IPO, improved visibility of the shipping company lowers its cost of credit for loans from banks and other financial institutions.
Proposition 3: Following an IPO, improved visibility of the shipping company increases its image and prestige to the stakeholders.

Proposition 4: Following an IPO, improved visibility of the shipping company increases the development of inter-organizational relationships.

To test these propositions, we first conducted a number of in-depth interviews with industry specialists that helped us understand the Greek tycoons' mindset and identify the sources of their success ${ }^{1}$. Then, we conducted our own survey of the 13 Greek shipping operators at that time listed in the US equity markets (NYSE and NASDAQ, 2006), which yielded 10 responses (76 per cent).

The survey was carried out through self-administered questionnaires filled in by the CEO of the company, while, only in three cases, we got feedback from the CFO. Except for one case, a minimum of six-month period lapsed between the listing date and the date the survey was conducted (January 2007), which allowed a feedback on both anticipated and actual IPO benefits -a unique feature of our study.

The questionnaire is in two parts. The first part relates a number of factors that were important on the decision of the company to go public in the US stock market. It includes the anticipated benefits such as 'To diversify sources of finance', 'To increase the visibility of the company', 'To facilitate ownership status restructuring'. The second part examines to what extent these benefits were achieved after the IPO. To assess the importance of each factor, the Likert scale from 1 to 7 was used, where 1 represents the least importance and 7 represents the most importance.

Table III summarizes the anticipated IPO benefits. Top on the list is financial diversification (mean score 6.60), followed by improved access to capital (6.20), and external growth stimulation (6.00). High up on the list are also the credit cost reduction, the better bargaining power with banks and institutions, followed by increased corporate visibility and improved corporate image.

Table IV summarizes the actual IPO benefits. Financial diversification continues to top the list followed by 
improved access to capital, too, but the external growth stimulation gives its place to the lower cost of credit. Other factors, such as the improvement of company image and prestige, and debt equity rebalancing have moved up on the list, while bargaining power with creditors has roughly maintained its ranking in both tables. So have actual IPO benefits met the expectations of Greek shipowners?

To address this question, we have calculated the "gap" between anticipated and actual benefits. For most factors addressed, actual benefits far exceed anticipated benefits (see Table V). This means that the IPO had a positive -beyond expectations- impact on certain business objectives. This is especially the case for four factors where the gap is larger and statistically significant, the building of inter-organizational relationships, the improvement of corporate image and prestige, the reaching of existing and potential stockholders, and the gaining of greater bargaining power with creditors (see Table VI).

These findings are further confirmed by the post-IPO benefits correlation coefficient matrix (see Appendix): The shipping companies' augmented visibility that followed the IPO is positively correlated with their bargaining power with potential creditors (correl. coeff.: 0.851 , sign. level: 0.05 ); the improved visibility and the positive signals of financial health is positively correlated with corporate creditworthiness, translating into lower credit costs (correl. coeff.: 0.707, sign. level: $0.05)$; the improved visibility is positively correlated with corporate reputation, image and prestige (correl. coeff.: 0.917 , sign. level: 0.01 ); the improved visibility is positively correlated with the development of genuine inter-organizational relationships and networks and the exploitation of entrepreneurial opportunities (correl. coeff.: 0.732, sign. level: 0.05).

Our findings are consistent with a number of similar studies. Pagano, Panetta \& Zingales (1998), for instance, find that the companies go public to rebalance their accounts after a period of high investment and growth rather than to simply raise equity capital. The authors further confirm that public companies experience a lower bank borrowing cost after the IPO. Rajan (1992) finds that access to equity markets and public information dissemination elicits competition among lenders that ensures a lower cost of credit. Ravassi \& Marchisio (2003) find that enhanced visibility and trustworthiness expands the number of opportunities for collaboration in new development initiatives.

\section{Conclusion}

An IPO has always been an appealing proposition for companies seeking to broaden and diversify their sources of financing, improve liquidity, and enhance corporate profile that translates to better internal and external relations. These benefits come at a cost, however, which includes listing and underwriting fees, compliance expenses, equity price concessions, and exposure to hostile takeovers.

While some of these costs and benefits are wellknown in advance, others aren't, especially when it comes to indirect benefits and that makes an IPO an uncertain proposition: the post IPO world may save positive or negative surprises. IPO costs and benefits are further sensitive to the prevailing economy, equity market and industry conditions at the time the IPO decision is under consideration that may tip the balance in either direction. A declining economy, a sagging equity market, and an industry in a cyclical downturn tip the point towards the costs. A growing economy, a rising equity market, and an industry in a cyclical upturn tip the point in favor of the listing benefits, especially for industry leaders, as has been the case with the 13 Greek shipping companies that floated their shares in US Exchanges in the early 2000s.

As our survey confirms, the listing has met and even exceeded Greek shipping companies' expectations: Broadened and diversified capital financing, improved image and prestige, strengthened bargaining power with creditors, and enhanced entrepreneurial opportunities-meeting and even exceeding their expectations. These findings are consistent with a number of similar studies.

Simultaneously, the paper has certain policy implications for companies considering going public. First, they should choose carefully the right place, the right exchange to list their shares. A reputable and 
visible exchange is far more effective in improving corporate image and prestige that eventually translates into tangible benefits such as the strengthening of bargaining power with creditors, the lowering of cost of credit, and the creation of entrepreneurial networks and opportunities. Second, they should choose the right time, that is when financial markets are in a bull phase and the industry they are in is in a cyclical upturn. Third, they should keep a closer eye on the indirect benefits of an IPO, rather than on the direct benefits of immediate capital growth. These implications can further be supported if this survey is also conducted in other highly globalized industries, in different business settings. $\boldsymbol{\Gamma}$.

\section{Note}

1 We have particularly benefited from the many constructive comments made by Mr. Konstantinos Voulgaris.

\section{References}

Amihud, Y. and Mendelson, H., 1988, "Liquidity and assets prices: financial management implications," Financial Management, 17 (1), 5-15.

Barry, C., Muscarella, C., Peavy, J. and Vetsuypens, M., 1990, 'The Role of Venture Capital in the Creation of Public Companies: Evidence from the Going Public Process', Journal of Financial Economics, 27 (2), 447-471.

Barry, C. B., Muscarella, C. J. and Vertsuypens, M. R., 1991, 'Underwriter Warrants, Underwriter Compensation, and the Costs of Going Public', Journal of Financial Economics, 29, 113-135.

Bauer, M. W. and Gaskell, G. (eds.), 2000, Qualitative Researching with Text, Image, and Sound: A Practical Handbook (London, U.K.: Sage Publications).

Brennan, M. J. and Franks, J., 1997 'Underpricing, Ownership and Control in Initial Public Offerings of Equity Securities in the UK', Journal of Financial Economics, 45, 391-413.

Black, B. S. and Gilson, R. J., 1998 'Venture Capital and the Structure of Capital Markets: Banks versus Stock Markets', Journal of Financial Economics, 47, 243-277.

Bolton, P. and Von Thadden, E., 1998 'Blocks, Liquidity, and Corporate Control', The Journal of Finance, 53 (1), 1-25.

Booth, J. R and Chua, L., 1996, 'Ownership Dispersion, Costly Information, and IPO Underpricing', Journal of Financial Economics, 41, 291-310.
Campbell, T., 1979, 'Optimal Investment Financing Decisions and the Value of Confidentiality', Journal of Financial and Quantitative Analysis, 14, 913-924.

Chemmanur, T. J. and Fulghieri, P., 1999, 'A Theory of the GoingPublic Decision', The Review of Financial Studies, 12 (2), 249-279.

Chen, H. C. and Ritter, J. R., 2000, 'The Seven Per Cent Solution', The Journal of Finance, 55 (3), 1105-1131.

Cook, D. O., Kieschnick, R. and Van Ness, R. A., 2006, 'On the marketing of IPOs', Journal of Financial Economics, 82 (1), 35-61.

Creswell, J. W., 1994, Research Design: Quantitative and Qualitative Approaches, London: Sage Publications.

Deeds D. L., Decarolis D. and Coombs J. E., 1997, 'The impact of firm-specific capabilities on the amount of capital raised in an initial public offering: evidence from the biotechnology industry', Journal of Business Venturing, 12 (1), 31-46.

Derrien, F. and Kecskés, A., 2007, 'The Initial Public Offerings of Listed Firms', The Journal of Finance, 62 (1), 447-479.

Fombrun, C. J. and C. Van Riel, 1998, 'The Reputational Landscape: A Convergence of Theory and Practice', Corporate Reputation Review, 1,5-13.

Frieder, L. and Subrahmanyam, A., 2005, 'Brand perceptions and the market for common stock', Journal of Financial and Quantitative Analysis, 40, 57-85.

Grammenos, C. T. and Choi, C. J., 1999, 'The Greek Shipping Industry', International Studies of Management and Organization, 29 (1), 34-52.

Grammenos, C. T. and Marcoulis, S., 1996, 'Shipping Initial Public Offerings: A Cross-Country Analysis', in Levis, M. (eds.), Empirical Issues in Raising Equity Capital, Oxford: Elsevier, pp. 379-400.

Hansen, R. S., 2001, 'Do Investment Banks Compete in IPOs?: The Advent of the ' $7 \%$ plus Contract', Journal of Financial Economics, 59, 313-346.

Holmstrom, B. and Tirole, J., 1993, 'Market Liquidity and Performance Monitoring', Journal of Political Economy, 101, 678-709.

Institute of Shipping Economics \& Logistics, 2006, ISL Shipping Statistics \& Market Review 2006, Retrieved Jan. 2, 2007, from the World Wide Web: www.isl.com.

Leland, H. E. and Pyle, D. H., 1977, 'Informational Asymmetries, Financial Structure, and Financial Intermediation', The Journal of Finance, 32 (2), 371-387.

National Association of Securities Dealers (NASDAQ), Financial Data, Retrieved July 21, 2005 and Nov. 6, 2006, from the World Wide Web: www.nasdaq.com.

New York Stock Exchange (NYSE), Financial Data, Retrieved Jul. 21 and Aug. 6, 2005, and Sept. 24, 2006, from the World Wide Web: www.nyse.com. 
Pagano, M., 1993, 'The Flotation of Companies on the Stock Market', European Economic Review, 37, 1101-1125.

Pagano, M., Panetta, F. and Zingales, L., 1998, 'Why Do Companies Go Public? An Empirical Analysis', The Journal of Finance, 53 (1), 2763.

Pagano, M. and Röell, A., 1998, 'The Choice of Stock Ownership Structure: Agency costs, Monitoring and the Decision to Go Public', Quarterly Journal of Economics, 113 (1), 187-225.

Pollock, T. G. and Gulati, R., 2007, 'Standing out from the crowd: the visibility-enhancing effects of IPO-related signals on alliance formation by entrepreneurial firms', Strategic Organization, 5 (4), 339372.

Rajan, R. G., 1992, 'Insiders and Outsiders: The Choice between Informed and Arm's-length Debt', The Journal of Finance, 47 (4), 1367-1400.

Ravasi, D. and Marchisio, G., 2003, 'Going Public and the Enrichment of a Supportive Network', Small Business Economics, 21 (4), 381-395.

Ritter, J. R., 1987, 'The Costs of Going Public', University of Michigan Working Paper No. 487, Retrieved Jul. 8, 2005, from the World Wide Web: www.hti.umich.edu.

Ritter, J. R., and Welch, I., 2002, 'A Review of IPO Activity, Pricing, and Allocations', The Journal of Finance, 57 (4), 1795-1828.

Ritter, J. R., 2003, 'Investment banking and securities issuance', in Constadinides, G., Harris, M. and Stulz, R. (eds.), Handbook of the Economics of Finance, pp. 255-306.
Rock, K, 1986, 'Why new issues are underpriced', Journal of Financial Economics, 15, 187-212.

Röell, A., 1996, 'The Decision to Go Public: An Overview', European Economic Review, 40 (3-5), 1071-1081.

Stefanidis, A., loannidis, A. and Mourdoukoutas, P., 2007, 'Entrepreneurial Networks in Highly Globalised Industries: The Case of the Greek Shipping Industry', International Journal of Networking and Virtual Organizations, 4 (2), 189-200.

United Nations Conference on Trade and Development - UNCTAD Secretariat, 2006, Review of Maritime Transport 2006, New York and Geneva: United Nations.

Yin, R. K., 1994, Case Study Research, Design and Methods. Thousand Oaks, California, USA: Sage Publications.

Yahoo Finance, www.finance.yahoo.com

Yosha, O., 1995, 'Information Disclosure Costs and the Choice of Financing Source', Journal of Financial Intermediation, 4, 3-20.

Zingales, L., 1995, 'Insider Ownership and the Decision to Go Public', Review of Economic Studies, 62, 425-448.

\section{Tables}

\begin{tabular}{|c|l|c|l|}
\hline \multicolumn{1}{|c|}{ BENEFITS } & \multicolumn{1}{|c|}{ Direct } & \multicolumn{1}{|c|}{ Direct } \\
\hline 1 & $\begin{array}{l}\text { Access to direct financing, ownership restructuring } \\
\text { and exit strategy }\end{array}$ & 1 & Underwriting and offering registration fees \\
\hline 2 & $\begin{array}{l}\text { Improved liquidity and portfolio diversification for } \\
\text { current and potential investors }\end{array}$ & 2 & Investment banking costs \\
\hline 1 & $\begin{array}{l}\text { Augmented visibility and publicity that improves } \\
\text { corporate profile }\end{array}$ & 1 & Underpricing or adverse selection costs \\
\hline 2 & $\begin{array}{l}\text { Improved creditworthiness, greater bargaining power } \\
\text { with banks and financial institutions, lower cost of } \\
\text { credit }\end{array}$ & 2 & Compliance \\
\hline 3 & $\begin{array}{l}\text { Enhanced corporate credibility and development of a } \\
\text { network of inter-organizational relationships }\end{array}$ & 3 & Exposure to tax authorities scrutiny \\
\hline 4 & \begin{tabular}{l} 
Attractive compensation schemes for employees \\
\hline
\end{tabular}
\end{tabular}

Table 1: Benefits and Costs of Initial and Follow-on Public Offerings 


\begin{tabular}{|clcrrrrr|}
\hline Company & $\begin{array}{c}\text { Stock } \\
\text { Exchange }\end{array}$ & $\begin{array}{l}\text { Entry } \\
\text { Year }\end{array}$ & EBIT & Debt & $\begin{array}{c}\text { Interest } \\
\text { Expense }\end{array}$ & $\begin{array}{c}\text { Interest } \\
\text { Expense/ } \\
\text { EBIT }\end{array}$ \\
\hline 1 & Aries Maritime Transport Ltd. & Nasdaq & 2005 & $33,564,000$ & $284,800,000$ & $18,793,000$ & $55.99 \%$ \\
\hline 2 & Danaos Corporation & NYSE & 2006 & $146,265,000$ & $741,070,000$ & $23,415,000$ & $16.01 \%$ \\
\hline 3 & Diana Shipping Inc. & NYSE & 2005 & $67,721,000$ & $39,450,000$ & $2,731,000$ & $4.03 \%$ \\
\hline 4 & DryShips Inc. & Nasdaq & 2005 & $131,415,000$ & $577,200,000$ & $20,398,000$ & $15.52 \%$ \\
\hline 5 & Excel Maritime Carriers Ltd. & NYSE & 1999 & $77,608,000$ & $226,840,000$ & $9,538,000$ & $12.29 \%$ \\
\hline 6 & FreeSeas Inc. & Nasdaq & 2005 & 152,000 & $13,120,000$ & 0 & $0.00 \%$ \\
\hline 7 & General Maritime Corp. & NYSE & 2001 & $244,757,000$ & $50,000,000$ & $32,400,000$ & $13.24 \%$ \\
\hline 8 & Navios Maritime Holdings Inc. & Nasdaq & 2005 & $65,994,000$ & $545,380,000$ & $13,569,000$ & $20.56 \%$ \\
\hline 9 & Omega Navigation Enterprises Inc. & Nasdaq & 2006 & $12,260,000$ & $240,460,000$ & $4,204,000$ & $34.29 \%$ \\
\hline 10 & Quintana Maritime Ltd. & Nasdaq & 2005 & $10,895,000$ & $459,500,000$ & $5,367,000$ & $49.26 \%$ \\
\hline 11 & StealthGas Inc. & Nasdaq & 2005 & $17,221,000$ & $150,430,000$ & $2,685,000$ \\
\hline 12 & Top Tankers Inc. & Nasdaq & 2004 & $88,861,000$ & $564,100,000$ & $20,177,000$ & $15.59 \%$ \\
\hline 13 & Tsakos Energy Navigation Ltd. & NYSE & 2002 & $173,002,000$ & $1,110,000,000$ & $11,247,000$ \\
\hline
\end{tabular}

Source: Adapted from NYSE and NASDAQ, 2006

Table 2: Greek Shipping Companies Listed in the US Stock Exchanges and their Interest Expense

\begin{tabular}{|llc|}
\hline & Mean & Std. Deviation \\
\hline To broaden and diversify capital financing structure & 6.60 & 0.70 \\
\hline To achieve improved access to capital & 6.20 & 1.14 \\
\hline To stimulate external growth & 6.00 & 1.25 \\
\hline To lower cost of credit & 5.40 & 1.26 \\
\hline To rebalance the debt to equity level & 5.10 & 1.60 \\
\hline To reach efficiently groups of existing and potential stakeholders & 1.78 \\
\hline To gain greater bargaining power with banks and institutions & 1.50 \\
\hline To increase the visibility of the company & 4.30 & 2.28 \\
\hline To improve the image and prestige of the company & 4.10 & 1.49 \\
\hline To support establishment of strategic alliances & 3.30 & 1.69 \\
\hline To facilitate ownership status restructuring & 3.20 & 1.87 \\
\hline To build a network of inter-organizational relationships & 2.80 & 1.57 \\
\hline To let shareholders sell part of their stocks & 2.70 & 1.64 \\
\hline
\end{tabular}

Table 3: Anticipated IPO Benefits (Scale 1-7)

\begin{tabular}{|lll|}
\hline & Mean & Std. Deviation \\
\hline To broaden and diversify capital financing structure & 6.44 & 0.73 \\
\hline To achieve improved access to capital & 6.33 & 0.71 \\
\hline To lower cost of credit & 6.33 & 0.71 \\
\hline To stimulate external growth & 6.22 & 1.09 \\
\hline To improve the image and prestige of the company & 6.00 & 1.50 \\
\hline To rebalance the debt to equity level & 6.00 & 1.22 \\
\hline To reach efficiently groups of existing and potential stakeholders & 5.78 & 1.99 \\
\hline To increase the visibility of the company & 5.67 & 1.00 \\
\hline To gain greater bargaining power with banks and institutions & 5.56 & 1.42 \\
\hline To build a network of inter-organizational relationships & 4.44 & 1.66 \\
\hline To facilitate ownership status restructuring & 3.67 & 2.00 \\
\hline To let shareholders sell part of their stocks & 3.67 & 1.58 \\
\hline To support establishment of strategic alliances & 3.67 \\
\hline
\end{tabular}

Table 4: Actual IPO Benefits (Scale 1-7) 


\begin{tabular}{|l|l|}
\hline & GAP \\
\hline To broaden and diversify capital financing structure & -0.16 \\
\hline To achieve improved access to capital & 0.13 \\
\hline To stimulate external growth & 0.22 \\
\hline To support establishment of strategic alliances & 0.47 \\
\hline To facilitate ownership status restructuring & 0.87 \\
\hline To rebalance the debt to equity level & 0.90 \\
\hline To lower cost of credit & 0.93 \\
\hline To gain greater bargaining power with banks and institutions & 1.26 \\
\hline To reach efficiently groups of existing and potential stakeholders & 1.28 \\
\hline To let shareholders sell part of their stocks & 1.37 \\
\hline To increase the visibility of the company & 1.57 \\
\hline To build a network of inter-organizational relationships & 1.74 \\
\hline To improve the image and prestige of the company & 2.70 \\
\hline
\end{tabular}

Table 5: Anticipated and Actual IPO benefit Gap

\begin{tabular}{|lccc|}
\hline & t & df & Sig. (2-tailed) \\
\hline To build a network of inter-organizational relationships & -4.47 & 8 & 0.0021 \\
\hline To improve the image and prestige of the company & -4.08 & 8 & 0.0035 \\
\hline To reach efficiently groups of existing and potential stakeholders & -2.73 & 8 & 0.0260 \\
\hline To gain greater bargaining power with banks and institutions & -2.68 & 8 & 0.0278 \\
\hline To lower cost of credit & -2.29 & 8 & 0.0509 \\
\hline To increase the visibility of the company & -1.94 & 8 & 0.0883 \\
\hline To let shareholders sell part of their stocks & -1.74 & 8 & 0.1202 \\
\hline To rebalance the debt to equity level & -1.64 & 8 & 0.1388 \\
\hline To broaden and diversify capital financing structure & 1.15 & 8 & 0.2815 \\
\hline To support establishment of strategic alliances & -1.08 & 8 & 0.3122 \\
\hline To facilitate ownership status restructuring & -1.08 & 8 & 0.3129 \\
\hline To achieve improved access to capital & 0.43 & 8 & 0.6811 \\
\hline To stimulate external growth & -0.21 & 8 & 0.8417 \\
\hline
\end{tabular}

Table 6: Paired samples t-test of the expected benefits before the IPO and the achieved benefits after the IPO 


\section{Figures}

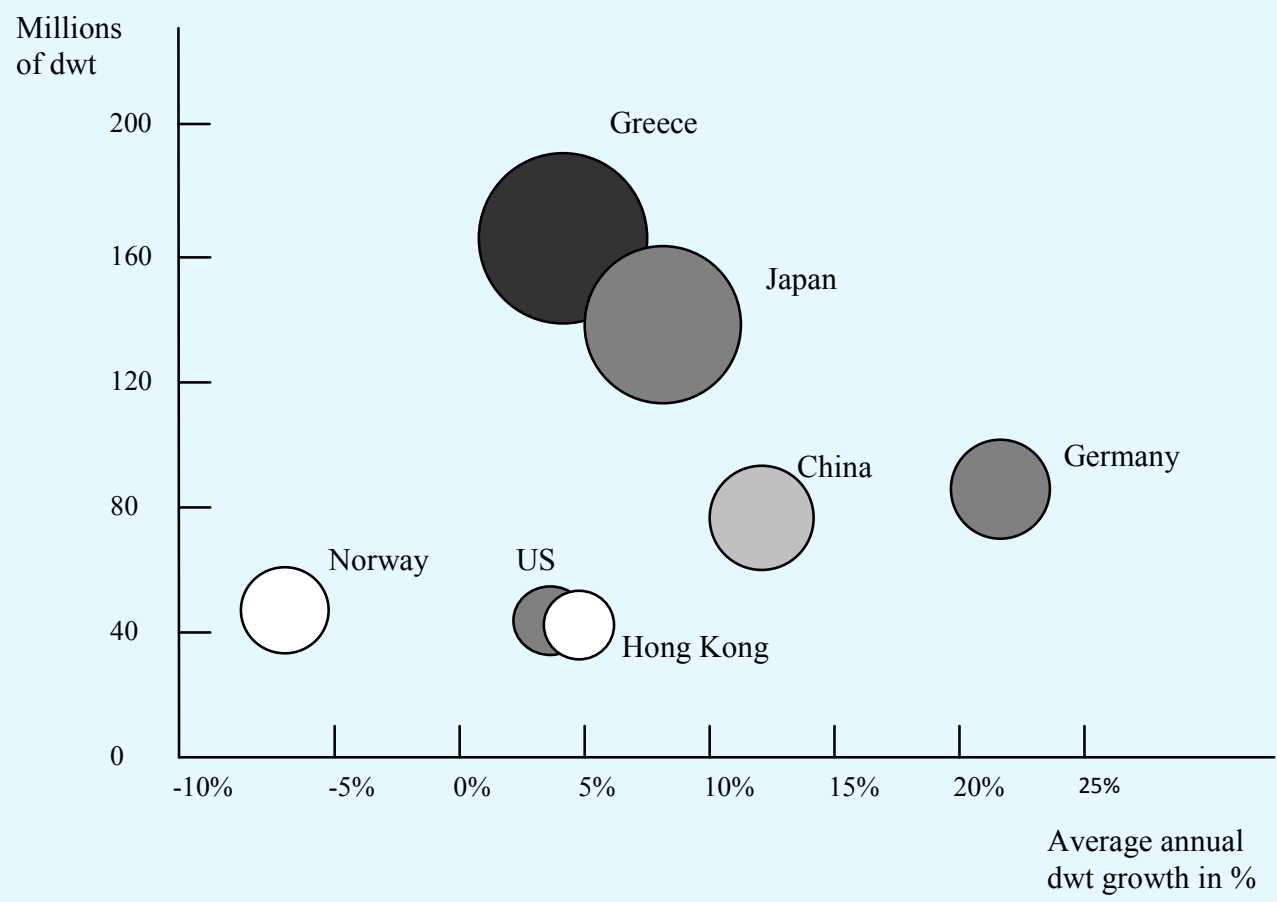

Figure 1: Controlled fleet growth of major shipping nations as of July $1^{\text {st }}, 2006$ (dwt - yearly average growth rate 2002-2006)

\section{Appendix: The correlation matrix}

\begin{tabular}{|c|c|c|c|c|c|c|c|c|c|c|c|c|c|c|}
\hline & & $\begin{array}{l}\begin{array}{l}\text { To broaden } \\
\text { and diversify } \\
\text { capital } \\
\text { financing } \\
\text { structure }\end{array} \\
\end{array}$ & $\begin{array}{l}\text { To increase the } \\
\text { visisilitity of the } \\
\text { company }\end{array}$ & \begin{tabular}{|l|}
$\begin{array}{l}\text { To facilitate } \\
\text { ownership status } \\
\text { restructuring }\end{array}$ \\
\end{tabular} & \begin{tabular}{|l}
$\begin{array}{l}\text { To support } \\
\text { establishment of } \\
\text { strategic alliances }\end{array}$ \\
\end{tabular} & \begin{tabular}{|l|} 
To gain greater \\
bargaining \\
power with \\
banks and \\
institutions
\end{tabular} & $\begin{array}{l}\text { To improve the } \\
\text { image and } \\
\text { prestige of the } \\
\text { company }\end{array}$ & \begin{tabular}{|l|} 
To let \\
shareholders sell \\
part of their \\
stocks
\end{tabular} & $\mid \begin{array}{l}\text { To stimulate } \\
\text { external growth }\end{array}$ & $\begin{array}{l}\text { To lower cost of } \\
\text { credit }\end{array}$ & \begin{tabular}{|l} 
To reach \\
efficiently groups \\
of existing and \\
potontial \\
stakeholders
\end{tabular} & $\begin{array}{l}\text { To achieve } \\
\text { improved } \\
\text { aceess to } \\
\text { capital }\end{array}$ & \begin{tabular}{|l} 
To build a network \\
of inter- \\
organzizational \\
relationships
\end{tabular} & \begin{tabular}{|l|}
$\begin{array}{l}\text { To rebalance the } \\
\text { debt to equity } \\
\text { level }\end{array}$ \\
\end{tabular} \\
\hline $\begin{array}{l}\text { To broaden and diversify } \\
\text { capital financing } \\
\text { strutcure }\end{array}$ & $\begin{array}{l}\text { Pears. Correl. } \\
\text { Sig. (2-ailed) }\end{array}$ & 1.00 & $\begin{array}{l}0.057 \\
0.883\end{array}$ & $\begin{array}{l}0.035 \\
0.930 \\
\end{array}$ & $\begin{array}{l}0.254 \\
0.510\end{array}$ & $\begin{array}{l}0.410 \\
0.274\end{array}$ & 0.253 & $\begin{array}{l}0.029 \\
0.942\end{array}$ & $\begin{array}{l}0.175 \\
0.653\end{array}$ & $\begin{array}{l}0.406 \\
0.279\end{array}$ & $\begin{array}{l}-0.010 \\
0.980\end{array}$ & $\begin{array}{c}-0.081 \\
0.836\end{array}$ & $\begin{array}{c}-0.456 \\
0.217\end{array}$ & $\begin{array}{l}0.281 \\
0.464\end{array}$ \\
\hline $\begin{array}{l}\text { tstructure } \\
\text { To increase the visility }\end{array}$ & \begin{tabular}{|l} 
Pears. Correl. \\
Pente
\end{tabular} & & 1.000 & $0.82^{9 * *}$ & 0.553 & $0.851 * * 1$ & $0.917 \ldots$ & $0.688^{*}$ & -0.381 & $0.707 \%$ & $0.462 \mathrm{r}-2$ & 0.177 & $0.732^{*}$ & 0.510 \\
\hline of the company & $\begin{array}{l}\text { Sig. (2-tailed) } \\
\mathrm{N}\end{array}$ & & & 0.006 & 0.122 & 0.004 & 0.001 & 0.041 & 0.311 & 0.033 & 0.211 & 0.649 & 0.025 & 0.160 \\
\hline $\begin{array}{l}\text { To facilitite ownership } \\
\text { status restructuring }\end{array}$ & $\begin{array}{l}\text { Pears. Correl. } \\
\text { Sig. (2-tailed) }\end{array}$ & & & 1.000 & $\begin{array}{c}0.667^{*} \\
0.050\end{array}$ & $\begin{array}{c}0.814^{4 * x} \\
0.008\end{array}$ & $\begin{array}{c}0.855^{4+4} \\
0.003\end{array}$ & $\begin{array}{c}0.905^{* k} \\
0.001\end{array}$ & $\begin{array}{c}-0.230 \\
0.552\end{array}$ & $\begin{array}{l}0.640 \\
0.064\end{array}$ & $\begin{array}{l}0.468 \\
0.204\end{array}$ & $\begin{array}{l}0.320 \\
0.402\end{array}$ & $\begin{array}{l}0.653 \\
0.057\end{array}$ & $\begin{array}{l}0.492 \\
0.178\end{array}$ \\
\hline To support establishm & Pears. Correl. & & & & 1.000 & $0.696^{*} \mid$ & 0.580 & 0.395 & $-0.675^{*}$ & 0.447 & 0.013 & -0.335 & 0.241 & 0.516 \\
\hline of strategic alliances & $\begin{array}{l}\text { Sig. (2-tailed) } \\
\mathrm{N}\end{array}$ & & & & & 0.037 & 0.102 & 0.292 & 0.046 & 0.227 & 0.973 & 0.378 & 0.533 & 0.155 \\
\hline 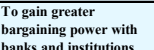 & \begin{tabular}{|l} 
Pears. Correl. \\
Sig. (2-talied)
\end{tabular} & & & & & 1.000 & $\begin{aligned} 0.955^{* k+} \\
0.000\end{aligned}$ & $\begin{aligned} 0.677^{*} \\
0.046\end{aligned}$ & $\begin{array}{c}-0.291 \\
0.447\end{array}$ & $\begin{array}{l}0.646 \\
0.060\end{array}$ & $\begin{array}{l}0.254 \\
0.509\end{array}$ & $\begin{array}{l}0.029 \\
0.940\end{array}$ & $\begin{array}{l}\begin{array}{l}0.471 \\
0.200\end{array} \\
\end{array}$ & $\begin{array}{l}0.407 \\
0.277\end{array}$ \\
\hline $\begin{array}{l}\text { To improve the image } \\
\text { and prestige of the } \\
\text { company }\end{array}$ & $\begin{array}{l}\text { Pears. Correl. } \\
\text { Sig. (2-tailed) }\end{array}$ & & & & & & 1.000 & $\begin{array}{c}0.708^{*} \\
0.033\end{array}$ & $\begin{array}{l}-0.305 \\
0.425\end{array}$ & $\begin{array}{c}0.707 * \\
0.033\end{array}$ & $\begin{array}{l}0.462 \\
0.211\end{array}$ & $\begin{array}{l}0.236 \\
0.542\end{array}$ & $\begin{array}{l}0.644 \\
0.061\end{array}$ & $\begin{array}{l}0.408 \\
0.275\end{array}$ \\
\hline $\begin{array}{l}\text { To let shareholders sell } \\
\text { part of their stocks }\end{array}$ & $\begin{array}{l}\text { Pears. Correl. } \\
\text { Sig. (2-ailed) }\end{array}$ & & & & & & & 1.000 & $\begin{array}{l}0.152 \\
0.695\end{array}$ & $\begin{array}{l}0.530 \\
0.142\end{array}$ & $\begin{array}{l}0.388 \\
0.302\end{array}$ & $\begin{array}{l}0.442 \\
0.234\end{array}$ & $\begin{array}{l}0.629 \\
0.070\end{array}$ & $\begin{array}{l}0.408 \\
0.275\end{array}$ \\
\hline & Ne-(z-tanced) & & & & & & & & & & & & & \\
\hline \begin{tabular}{|l|}
$\begin{array}{l}\text { To stimulate external } \\
\text { growth }\end{array}$ \\
\end{tabular} & $\begin{array}{l}\text { Pears. Correl. } \\
\text { Sig. (2-tailed) }\end{array}$ & & & & & & & & 1.000 & $\begin{array}{r}-0.270 \\
0.483 \\
\end{array}$ & $\begin{array}{c}-0.090 \\
0.819\end{array}$ & $\begin{array}{l}0.377 \\
0.317\end{array}$ & $\begin{array}{c}-0.312 \\
0.413\end{array}$ & $\begin{array}{c}-0.374 \\
0.322\end{array}$ \\
\hline To lower cost of credit & $\begin{array}{l}\text { Pears. Correl. } \\
\text { Sig. (2-tailed) }\end{array}$ & & & & & & & & & 1.000 & $\begin{array}{r}0.771^{11} \\
0.015\end{array}$ & $\begin{array}{l}0.500 \\
0.170\end{array}$ & $\begin{array}{l}0.455 \\
0.218\end{array}$ & $\begin{array}{c}0.866^{* *} \\
0.003\end{array}$ \\
\hline $\begin{array}{l}\text { To reach efficiently } \\
\text { groups of existing and } \\
\text { potential stakeholdersters }\end{array}$ & $\begin{array}{l}\text { Pears. Correl. } \\
\text { Sig. (2-tailed) }\end{array}$ & & & & & & & & & & 1.000 & $\begin{array}{c}0.860^{* *+} \\
0.003\end{array}$ & $\begin{array}{l}0.437 \\
0.239 \\
\end{array}$ & $\begin{array}{l}0.565 \\
0.113\end{array}$ \\
\hline $\begin{array}{l}\text { To achieve improved } \\
\text { aceess to capital }\end{array}$ & $\begin{array}{l}\text { Pears. Correl. } \\
\text { Sig (2-tailed) }\end{array}$ & & & & & & & & & & & 1.000 & $\begin{array}{l}0.331 \\
0.384\end{array}$ & $\begin{array}{l}0.289 \\
0.451\end{array}$ \\
\hline $\begin{array}{l}\text { To build a network of } \\
\text { inter-roganiz } \\
\text { relationships }\end{array}$ & $\begin{array}{l}\text { Pears. Correl. } \\
\text { Sig. (2-tailed) } \\
\text { N }\end{array}$ & & & & & & & & & & & & 1.000 & \begin{tabular}{l|l}
0.358 \\
0.344
\end{tabular} \\
\hline $\begin{array}{l}\text { To robalance the debt to } \\
\text { equity level }\end{array}$ & $\begin{array}{l}\text { Pears. Correl. } \\
\text { Sig. (2-tailed) }\end{array}$ & & & & & & & & & & & & & 1.000 \\
\hline
\end{tabular}

